\title{
GADD45a regulates cell proliferation and DNA repair of BRL-3A cells that treated by FZD/UVC via P38, JNK, CDC2/CCNB1, AKT and MTOR pathways
}

\author{
Xianguang Yang ${ }^{\mathrm{a}, \mathrm{b},{ }^{*}}$, Lin Zhu ${ }^{\mathrm{a}, \mathrm{b}}$, Weiming Zhao ${ }^{\mathrm{a}, \mathrm{b}}$, Chuncui He${ }^{\mathrm{a}, \mathrm{b}}$, Shuaihong $\mathrm{Li}^{\mathrm{a}, \mathrm{b}}$ and Cunshuan Xu ${ }^{\mathrm{a}, \mathrm{b}}$ \\ ${ }^{\text {a }}$ College of Life Science, Henan Normal University, Xinxiang 453007, Henan Province, China; \\ ${ }^{\mathrm{b}}$ State Key Laboratory Cultivation Base for Cell Differentiation Regulation and Henan Bioengineering
}

Key Laboratory, Henan Normal University, Xinxiang 453007, Henan Province, China;

\section{ABSTRACT}

GADD45 $\alpha$ is a stress-induced gene activated by a variety of stress stimuli, including ultraviolet and ionizing radiation, and involved in cell cycle regulation, apoptosis, maintenance, genomic stability, DNA repair and immune response. However, the effects and regulatory mechanism of GADD45 $\alpha$ on proliferation, apoptosis and DNA damage repair of hepatocytes in liver regeneration remains unclear. In this study overexpression of GADD45 $\alpha$ significantly inhibited the cell viability, proliferation, the number of cells in G1 and S phases, and of furazolidone (FZD) or UVC induced apoptosis of BRL-3A cells and decreased the inhibition of FZD/UVC on the viability, proliferation of BRL-3A cells, while increased the number of cells in G2/M phase of BRL-3A cells and FZD/UVC induced S phase arrest. Downregulated GADD45 $\alpha$ induced the viability, proliferation, the number of cells in $\mathrm{S}$ and G2/M phases and the inhibition of FZD/UVC on the viability, proliferation of BRL-3A cells increased, while decreased apoptosis, the number of cells in G1 phases of BRL-3A cells and FZD/UVC induced S phase arrest. The results of qRT-PCR and western blot showed that genes/proteins related to P38MAPK, JNK, CDC2/CCNB1, AKT and MTOR signaling pathways were significantly changed in normal BRL-3A cells. The expression profiles of cell cycle, proliferation and apoptosis related genes/proteins in FZD/UVC treated BRL-3A cells were also detected by qRT-PCR and western blot, and the results indicated that the expression of Myc, Bcl-2, Ccnd1, PCNA, P21, Ccnb1, Caspase3, Caspase8, Caspase9 and Bax have significantly changes.

Key words: GADD45 $\alpha$; liver regeneration; proliferation; DNA repair; apoptosis 


\section{Introduction}

After partial hepatectomy(PH), the remnant liver cells quickly re-enter the cell cycle from G0 phase, and restore liver quality and function with two cell cycle, which was called liver regeneration (Michalopoulos and DeFrances, 1997). In this process, hepatocytes divided rapidly, which increased the risk of DNA damage during DNA replication (Saintigny et al., 2001). The mechanism of hepatocyte proliferation and DNA damage repair during liver regeneration is not clear.

Growth arrest and DNA damage inducible $45 \alpha$ (GADD45 $\alpha$ ) is a stress-induced gene and its' transcription can be activated by various stress, including ultraviolet (Lapeyre et al., 1987), arsenite (Chang et al., 2007), Hypoxia and ionizing radiation, etc. and regulate cell cycle (Wang et al., 1999), apoptosis (Gupta et al., 2006), maintain genomic stability, and DNA methylation excision/repair (Li et al., 2015). GADD45 $\alpha$ can interact with key cell cycle regulatory factors such as p21 (Kearsey et al., 1995), cdc2/cyclinB1 (Vairapandi et al., 2002), PCNA (Vairapandi et al., 2000) and p38 (Bulavin et al., 2003). The expression of GADD45a in rats liver regeneration(LR) after PH was detected by rat Genome 230 2.0, and the results showed that GADD45a was significantly up-regulated in priming phase $(0-6 \mathrm{~h})$ and progressing phase $(12-72 \mathrm{~h})$, suggesting that GADD45 $\alpha$ may be involved in DNA damage repair and cell proliferation during rat LR after $\mathrm{PH}$.

In this paper, the signal pathway of GADD45 $\alpha$ was built and its' possible mechanism was analyzed by IPA software, QIAGEN and KEGG website. The mechanism of GADD45 $\alpha$ on the proliferation, cell cycle, apoptosis and DNA damage repair of BRL-3A cells and BRL-3A cells induced by FZD/UVC were studied by gene overexpression and gene interference. The effects of GADD45 $\alpha$ expression on the cell viability, proliferation and apoptosis of BRL-3A and FZD/UVC-induced BRL-3A cells were analyzed by MTT, EdU and flow cytometry. The GADD45 $\alpha$ signaling pathways related gene and protein expression profiles were detected by qRT-PCR and western Blot. And the regulatory mechanism of GADD45 $\alpha$ on liver cell proliferation, cell cycle, apoptosis and DNA damage repair were analyzed by the above results.

\section{Materials and methods}

\subsection{Recombinant plasmid construction}

TRNzol reagent (TAIGEN) was used to extract total RNA from fresh Rat liver tissue, then 
the RNA was reverse-transcribed to cDNA with a reverse transcription kit (Promage) for reverse-transcription polymerase chain reaction (RT-PCR). The PCR product of GADD45 $\alpha$ (GenBank sequence NM_024127.2, forward primer, 5'- CTCTAGAATGACTTTGGAGGAATTCTC-3'; reverse primer, 5'-ATAAGAATGCGGCCGCTCACCGTTCGGGGAGATTAA-3'.) was ligated into the pCDH-CMV-MCS-EF1-copGFP Vector. The recombinant plasmid was confirmed by RCR and double restriction enzymes digestion (Not1/XbaI).

\subsection{Package and harvest of lentivirus that overexpress of GADD45a}

The method of Ding et al. (Ding et al., 2016) was used to package the lentivirus. Recombinant plasmid pCDH-CMV-MCS-EF1-copGFP-GADD45 $\alpha$ was synthesized by Generay (Shanghai, China). Together with $15 \mu \mathrm{g}$ helper plasmid pSPAX2, $10 \mu \mathrm{g}$ helper plasmid pMD2.G, and $50 \mu \mathrm{L} \mathrm{CaCl}_{2}(2.5 \mathrm{M}), 20 \mu \mathrm{g}$ recombinant plasmid were added into a clean $1.5 \mathrm{~mL}$ microcentrifuge tube, and then sterile water was added to $500 \mu \mathrm{L}$, then the above system was added to $500 \mu \mathrm{L} 2 \times \mathrm{BES}$ ( $50 \mathrm{mM}$ BES, $280 \mathrm{mM} \mathrm{NaCl}, 1.5 \mathrm{mM} \mathrm{Na}_{2} \mathrm{HPO}_{4}$ ) to stand for 20 mins. The medium of HEK293T cells was replaced by DMEM-High glucose medium with 5\% serum, and $\mathrm{CaCl}_{2}$ system was added into the medium. After 12-16 hours, the medium was replaced with DMEM-High glucose medium with $2 \%$ serum. After another 36 hours, the virus particles were collected by passing through a $0.45 \mu \mathrm{m}$ filter, and were concentrated by ultrafiltration tubes $\left(10,000 \mathrm{MWCO}\right.$, Millipore, Massachusetts, USA) at $4000 \mathrm{~g}\left(4^{\circ} \mathrm{C}\right)$ for 20 mins. The concentrated virus particles were suspended in PBS and stored at $-80^{\circ} \mathrm{C}$.

\subsection{Transduction of BRL-3A cell}

Transduction was performed in 24-well plates. BRL-3A cells were seeded at $5 \times 10^{4}$ cells per well. One day later, the cells were transduced with $2 \times 10^{5} \mathrm{TU}$ virus particles. 24 hours post transduction, the medium was replaced with DMEM-High glucose medium with $10 \%$ serum. After another two days, the transduction efficiency was measured by detecting the green fluorescent protein (GFP) under fluorescence microscope. BRL-3A cells transfected with recombinant plasmid pCDH-CMV-MCS-EF1-copGFP-GADD45 $\alpha$ (experimental group, EG) and empty vector pCDH-CMV-MCS-EF1-copGFP (Normal control, NC) were collected after culturing in large scale. qRT-PCR and western blot were used to detect the expression changes of genes/proteins of GADD45 $\alpha$ during EG and NC groups.

\section{4. siRNA transfection of Cells}


BRL-3A cells were seeded at $5 \times 10^{4}$ cells per well. The next day when the cells were $60-70 \%$ confluent, the culture medium was replaced by fresh DMEM. $3 \mu$ L Lipofectamine ${ }^{\circledR}$ RNAiMAX Reagent and $50 \mathrm{pM}$ siRNA were added into $50 \mu \mathrm{L}$ DMEM respectively. Then Add diluted siRNA to diluted Lipofectamine ${ }^{\circledR}$ RNAiMAX Reagent (1:1 ratio) and incubate for 5 minutes at room temperature. Finally, $50 \mu \mathrm{L}$ siRNA-lipid complex were added into one well which contained 450 $50 \mu \mathrm{L}$ DMEM. Then the cells were cultured for 6 hours, and its' media were changed to fresh complete DMEM. The cells were harvested at $48 \mathrm{~h}$ after transfection.

\subsection{FZD treatment and UV irradiation}

FZD was dissolved in dimethyl sulfoxide (DMSO) to make a stock solution of $50 \mathrm{mg} / \mathrm{mL}$ and further diluted to corresponding concentrations with the cell culture medium. BRL-3A cells were cultured in the medium as mentioned above in 96 -well plates at a density of $1.5 \times 10^{4}$ cells per well. After culture for $24 \mathrm{~h}$, the cells were exposed to different concentrations of FZD (0, 12.5, 25,50 and $100 \mu \mathrm{g} / \mathrm{mL}$ ) or UV light is $30 \mathrm{~cm}$ below the UVC irradiation $0,15,30,45$ and $60 \mathrm{~s}$. The cell viability was determined by MTT assay as previously described. The absorbance at $490 \mathrm{~nm}$ at $24 \mathrm{~h}$ after treatment was measured by Biotek reader (ELx800, USA). The cell viability and cytotoxicity were estimated as the percentage of the control

\subsection{Comet Assay}

DNA damage was evaluated through the alkaline single cell gel electrophoresis (comet) assay. $5 \times 10^{6}$ cells were collected and added to 100 PBS. $100 \mu \mathrm{L} 0.8 \%$ normal elting point agarose was dropped onto slides, and t covered with a glass overslip. The slides were maintained at $4{ }^{\circ} \mathrm{C}$ for 10 min; verslips were removed, and $15 \mu \mathrm{L}$ of treated cells were mixed with $60 \mu \mathrm{L}$ of $0.6 \%$ low melting point agarose in PBS at $37^{\circ} \mathrm{C}$ and spread onto slides for $10 \mathrm{~min}$ at $4{ }^{\circ} \mathrm{C}$. The final ayer of $70 \mu \mathrm{L}$ of $0.6 \%$ low melting point agarose was applied in the same way. The slideswithout coverslips were immersed in a cell lysate with $10 \%$ DMSO at $4{ }^{\circ} \mathrm{C}$ for $2 \mathrm{~h}$ and then placed in electrophoresis buffer ( $1 \mathrm{mmol} / \mathrm{L}$ of EDTA, $300 \mathrm{mmol} / \mathrm{L}$ of $\mathrm{NaOH}, \mathrm{pH}>13)$ in an electrophoresis tank for 20 min to allow alkaline unwinding. Electrophoresis was performed for 20 min under 25 $\mathrm{V}$ and $300 \mathrm{~mA}$. The slides were then transferred to $0.4 \mathrm{mmol}$ Tris-buffer ( $\mathrm{pH} 7.5$ ), washed twice for 10 mins. Comets were stained with propidium iodide $(2 \mu \mathrm{g} / \mathrm{mL})$ and analyzed under a confocal laser scanning microscope (Nikon, Tokyo, Japan). Image analysis and tail moment were performed with CASP 1.2.2 software (Wroclaw, Silesia, Poland); 25 cells were randomly selected 
per sample.

\subsection{Cell Proliferation Assay}

Cells were treated by the methods above. Then $10 \mu \mathrm{L}$ MTT solution $(5 \mathrm{mg} / \mathrm{mL}$ in PBS) (Geneview, USA) were added to each well at 24,48 and $72 \mathrm{~h}$, and the cells were incubated for 4 hours in the dark at $37{ }^{\circ} \mathrm{C}$. Then, the medium was replaced with $100 \mu \mathrm{L}$ dimethylsulfoxide (DMSO) (Sigma-Aldrich, USA) for 10 mins to dissolve the formazan crystals produced by cells. Subsequently, the absorbance at $490 \mathrm{~nm}$ was measured by Biotek reader (ELx800, USA).

EdU detection was performed as the 5-ethynyl-2'-deoxyuridine (EdU) labeling/detection kit (Ribobio, Guangzhou, China). Cells were seeded and treated with the methods above, after 46 hours, the medium were replaced with new DMEM-High glucose medium containing $50 \mu \mathrm{M}$ EdU for $2 \mathrm{hr}$ incubation at $37{ }^{\circ} \mathrm{C}$ under $5 \% \mathrm{CO}_{2}$. After fixation with $4 \%$ paraformaldehyde $(\mathrm{pH} 7.4)$ for $30 \mathrm{~min}$ and glycine for $5 \mathrm{~min}$, anti-EdU working solution was added for reaction at room temperature in dark for 30 mins. Then cells were washed with $0.5 \%$ TritonX-100 and incubated with $5 \mathrm{~g} / \mathrm{ml}$ Hoechst 33342 dye at room temperature in dark for 30 mins. Cells were visualized under a fluorescence microscope.

\subsection{Flow cytometric analysis}

Cells were collected at $48 \mathrm{~h}$ after treatment, and washed with PBS followed by fixation in $70 \%$ ethanol for 12 hours on ice. After washing with PBS, cells were incubated in PBS with $0.2 \mathrm{mg} / \mathrm{mL}$ RNase (Solarbio, China) at $37^{\circ} \mathrm{C}$ for 30 mins. Then cells were stained with PI ( $20 \mu \mathrm{g} / \mathrm{ml}$, Sigma, USA) in dark for 15 mins. Finally, the stained nuclei were counted by flow cytometry and the cell cycle profile was analyzed by the FlowJo software.

Cells were subsequently harvested with $0.25 \%$ trypsin without EDTA, washed twice with cold PBS and resuspended in $500 \mu \mathrm{L}$ binding buffer $\left(1 \times 10^{6}\right.$ cells $\left./ \mathrm{mL}\right)$. Then cells were incubated with $5 \mu \mathrm{L}$ PE Annexin $\mathrm{V}(40 \mu \mathrm{g} / \mathrm{mL})$ and $5 \mu \mathrm{L}$ 7-AAD $(40 \mu \mathrm{g} / \mathrm{mL})$ in the dark for 15 min at room temperature and the cell apoptosis condition were detected by flow cytometry.

\subsection{Identification of GADD45a signaling pathway}

Previous studies have reported that GADD45 $\alpha$ could be activated by UV/Ionizing Radiation, and then exert its function via $\mathrm{CDC} 2 / \mathrm{CCNB} 1, \mathrm{mTOR}, \mathrm{P} 21$, and PCNA signaling pathway. Therefore, "CDC2/CCNB1 signaling pathway", "mTOR signaling pathway", "P21 signaling pathway" , "PCNA signaling pathway" and were entered into the "Pathway and Function" of 
Ingenuity Pathway Analysis (IPA) software respectively to obtain the interaction network of them and GADD45 $\alpha$, and the above results were filtered and integrated by researching the signaling pathway maps at the databases including GenMAPP, KEGG, BIOCARTA, QIAGEN and Biocompare, and then network of GADD45a-mediated signaling pathway were reconfirmed by pertinent articles.

\subsection{0. $q R T-P C R$}

Cells were seeded and treated according to the methods above and collected at $48 \mathrm{~h}$ after the treatment. The total RNA was extracted using TRNzol according to the manufacturer's instructions. Total RNA $(2 \mu \mathrm{g})$ was reverse-transcribed using random primers and reverse transcription kit (Promega, Madison, USA).The primers for the genes involved in GADD45 $\alpha$ signaling pathway were designed by Primer Express 5.0 software (Tab 1). The PCR was performed under the conditions with SYBG I: 2 min at $95{ }^{\circ} \mathrm{C}$, followed with 40 cycles for $15 \mathrm{~s}$ at $95{ }^{\circ} \mathrm{C}, 15 \mathrm{~s}$ at the corresponding annealing temperature, and $30 \mathrm{~s}$ at $72{ }^{\circ} \mathrm{C}$. $\beta$-actin was used as an internal reference. Each sample was performed in triplicates.

Tab 1.The primer sequences of genes for qRT-PCR

\begin{tabular}{|c|c|c|}
\hline Genes & Forward primer & Reverse primer \\
\hline Chkl & 5'-CCTCTTGGATGAAAGGGATAA-3' & 5'-CTCTGGAGCGACATAAGGTAA-3' \\
\hline$N f \kappa b 1$ & 5'-TGCATTCTGACCTTGCCTATC-3' & 5'-AGCCTGCTGTTCTGTCCATTC-3' \\
\hline Mapk14 & 5'-CAGTGGCTGACCCTTATGAC-3' & 5'-GGCACTTGAATGGTATTTGGA-3' \\
\hline Hsp27 & 5'-AGCACGAAGAAAGGCAGGATGA-3' & 5'-CCTCGAAAGTGACCGGAATGG-3' \\
\hline Mapk10 & 5'-ACCCCCTTTCCCGTAGATGA-3' & 5'-ACGTGTTTGTCGAATCCCTGA-3' \\
\hline Bcl-2 & 5'-CGACCTCTGTTTGATTTCTCCTG-3' & 5'-CTTTTCATATTTGTTTGGGGCA-3' \\
\hline$M y c$ & 5'-CCCTACCCGCTCAACGACA-3' & 5'-GCCTCTTTTCCACAGACACCA-3' \\
\hline Jun & 5'-GGCTGTTCATCTGTTTGTCTTCAT-3' & 5'-CCCTTTTCTTTACGGTCTCGGT-3' \\
\hline Ccndl & 5'-AAAATGCCAGAGGCGGATGA-3' & 5'-GAAAGTGCGTTGTGCGGTAG-3' \\
\hline Ccna2 & 5'-CTTTTAGTGCCGCTGTCTCTTT-3' & 5'-GCCCGCATACTGTTAGTGATGT-3' \\
\hline Caspase8 & 5'-ATATCCCAGATGAGGCAGAC-3' & 5'-GGGTTGTCTTTATTGCTCACATCAT-3' \\
\hline Mapk8 & 5'-ATTTGGAGGAGCGAACTAAG-3' & 5'-CTGCTGTCTGTATCCGAGGC-3' \\
\hline Aktl & 5'-GGTTGCCCACACGCTTACT-3' & 5'-GTTCTCCAGCTTGAGGTCCC-3' \\
\hline Akt3 & 5'-CAGACGGCTCATTCATAGGCT-3' & 5'-TGTATTTGGCTTTGGTCGTTC-3' \\
\hline Ccnbl & 5'-ACAACGGTGAATGGACACCA-3' & 5'-GCCACGGTTCACCATGACTA-3' \\
\hline$P 21$ & 5'-CACAGCAGGTCAAGAGGAGTA-3' & 5'-TCCTGAGCCTGTTTCGTGTCT-3' \\
\hline Bax & 5'TTTCATCCAGGATCGAGCAG-3' & 5'CAAAGTAGAAGAGGGCAACCAC-3' \\
\hline caspase3 & 5'-CTTCAGTGGTGGACATGACG-3' & 5'-TCAACAATTTGAGGCTGCTG-3' \\
\hline caspase 9 & 5'-AGCCAGATGCTGTCCCATAC-3' & 5'-CAGGAACCGCTCTTCTTGTC-3' \\
\hline
\end{tabular}




\section{Gadd45 2'-CTGGAGGAAGTGCTCAGCAAGG-3'

\subsection{Western blot analysis}

Cells were seeded and collected as described in the above methods, equal amounts of total proteins $(20 \mu \mathrm{g})$ were separated by SDS-PAGE, and then transferred onto a nitrocellulose membrane("PALL Corporation", USA).After the transfer, the membrane was blocked with 5\% skimmed milk in Tris-buffered saline (TBS) for 1 hour and subsequently incubated overnight at $4^{\circ} \mathrm{C}$ with the antibodies ( $\beta$-ACTIN, NF-KB1, JUN, CCNB1, BCL-2, MYC, CASPASE3, CASPASE8, CASPASE9, PCNA and P21, Cell Signaling Technology) against proteins-related to GADD45A signaling pathway at a dilution of 1:500. After washing with TBS containing $0.02 \%$ Tween- 20 for $30 \mathrm{~min}$ at room temperature, the membrane was further incubated with alkaline phosphatase labelled secondary antibodies goat anti-rabbit/mouse IgG ("Sigma," Germay) at a dilution of 1:1 000 for 1 hour. Finally, protein bands were visualized with BCIP/NBT. Image QuantTMTL ("Sigma", Germay) was used to measure the relative abundances of target proteins. $\beta$-ACTIN at a dilution of 1:1000 was served as an internal reference.

\subsection{Statistical analysis}

All the experiments were repeated for three times. Data was expressed as mean \pm SD. One-way analysis of variance (ANOVA) followed by a LSD test was used to compare experimental values between groups. Symbol * indicates $P<0.05$ and symbol $* * P<0.01$.

\section{Results}

\subsection{Identification of GADD45 $\alpha$ overexpression vector}

The recombinant plasmid was confirmed by RCR and double restriction enzymes digestion, and the results showed that the length of PCR and double restriction enzymes digestion product were consistent with the known GADD45 $\alpha$ gene (Fig 1). 
A

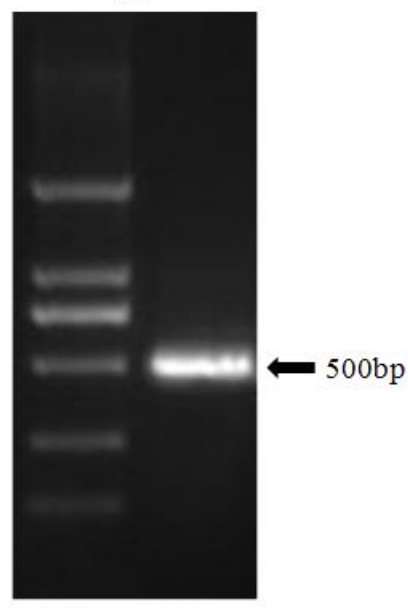

1

2

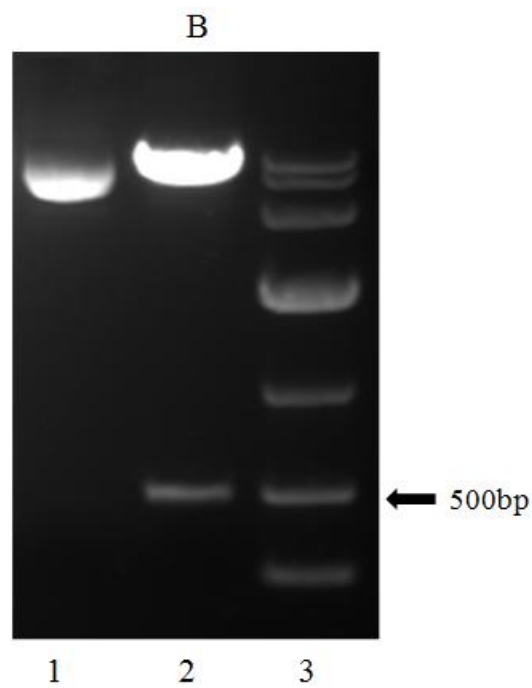

Fig 1. Identification of GADD45 $\alpha$ recombinant plasmid. A: PCR identification, 1: 2000 Marker, 2:

Purpose band, B: Identification of double restriction enzymes digestion, 1:

PCDH-CMV-MCS-EF1-copGFP-GADD45 $\alpha$. 2: Not1/XbaI double restriction enzymes digested, 3 : 10000 Marker.

\subsection{GADD45 $\alpha$ was highly expressed in BRL-3A cells}

The transduction efficiency was measured by observance of the GFP under fluorescence microscope at $48 \mathrm{~h}$ after the transduction. The results showed that recombinant plasmid pCDH-CMV-MCS-EF1-copGFP-GADD45 $\alpha$ was transduced into the BRL-3A cells successfully

(Fig 2). qRT-PCR and Western blot were used to detect the expression of GADD45 $\alpha$ in EG and NC groups, and the results indicated that the expression of GADD45 $\alpha$ in EG was markedly increased than that of NC(Fig 3).
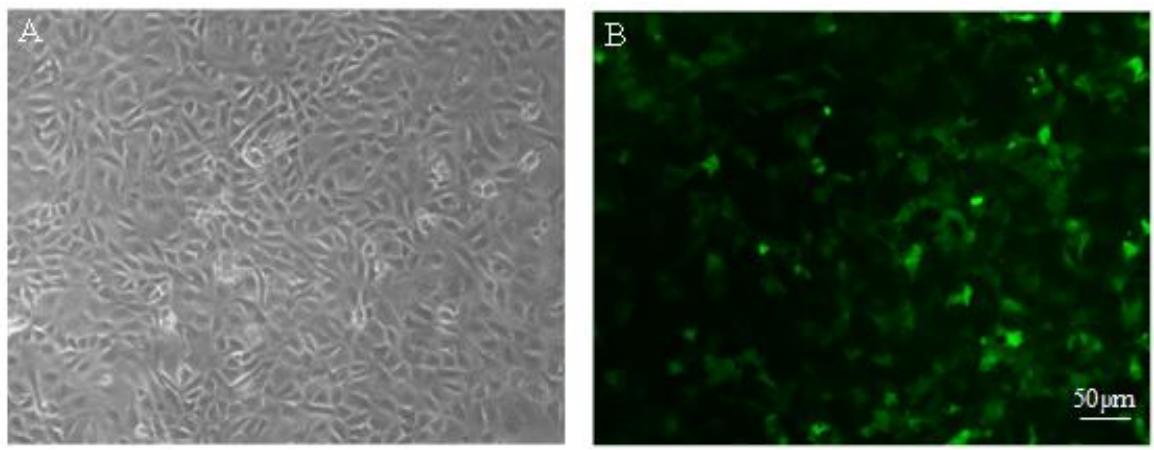

Fig 2. Efficient infection with recombinant plasmid in BRL-3A cells. A: white light, B: green fluorescence 


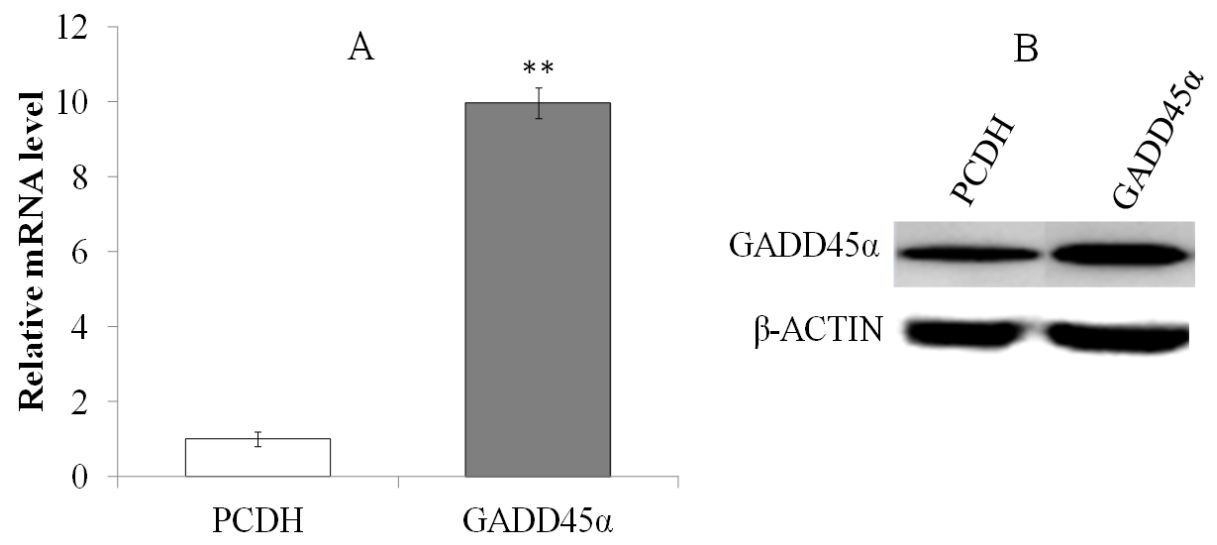

Fig 3. Expression changes of GADD45 $\alpha$ between EG and NC. A: qRT-PCR, B: Western blot. $* * p<0.01$

\subsection{Suppression of GADD45a expression by siRNA in BRL-3A Cells}

The Negative control (NC)、siRNA1、siRNA2、siRNA3 was transfected into BRL-3A cells, and the interference efficiency on GADD45a mRNA levels were determined by comparison with control group by quantitative real-time PCR at the time points, and the results indicated that their interference efficiency were $56.47 \pm 2.31 \%, 12.95 \pm 2.65 \%, 24.21 \pm 4.58 \%$ (Fig. 4). Accordingly, siRNA1 was selected as an effective interference fragment for the later study.

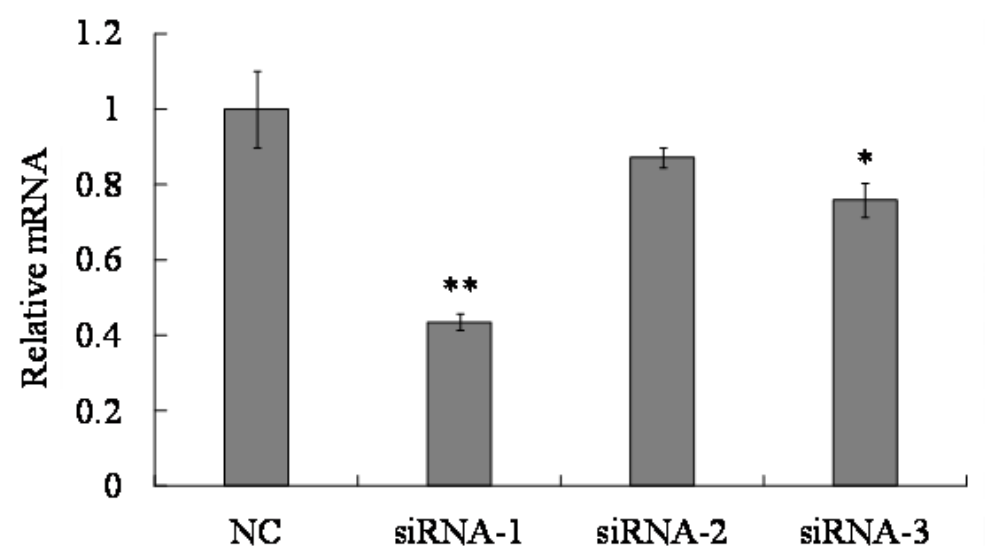

Fig 4. The interference efficiency of siRNAs. $* p<0.05 ; * * p<0.01$

\subsection{Cell viability inhibition by FZD or UVC}

After treating with $12.5,25,50$ and $100 \mu \mathrm{g} / \mathrm{mL} \mathrm{FZD}$, cell viability at $24 \mathrm{~h}$ were decreased by $22.12 \pm 1.02 \%, 37.15 \pm 2.12 \%, 49.91 \pm 2.51 \%$ and $77.94 \pm 1.34 \%$, respectively. Cells were exposed to UVC for $15,30,45$ and $60 \mathrm{~s}$, and cell viability decreased by $31.42 \pm 0.95 \%, 49.13 \pm 2.01 \%$, $75.76 \pm 2.32 \%$ and $80.52 \pm 1.57 \%$ at $24 \mathrm{~h}$ after treatment respectively. Accordingly, $50 \mu \mathrm{g} / \mathrm{mL}$ FZD and exposed to UVC for $30 \mathrm{~s}$ were optimized to be as an effective condition for the later study. 
(Fig 5).
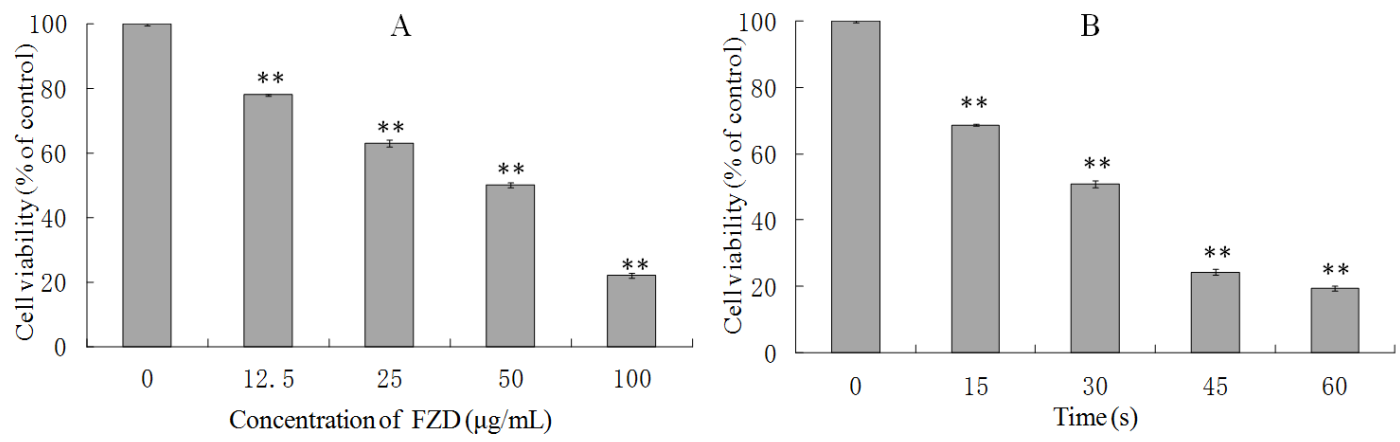

Fig 5. The survival ratios of BRL-3A cells after FZD (A) and UVC (B) treatment. **p< 0.01 , compared with control group.

\subsection{FZD and UV-Induced DNA Damage by Comet Assay}

DNA fragment that caused by FZD treatment and UV irradiation was demonstrated by comet assay (Fig 6). The fragmented DNA, especially the small fragments of DNA, can enter agarose gel easily, the more (smaller) fragments, the longer the tail becomes. The results indicated that the nuclear of the control group were round and there were no tailing, and there were obvious tailing in the experiment groups treated with FZD and UVC irradiation. The results showed that both FZD treatment and UVC irradiation will lead to DNA damage.
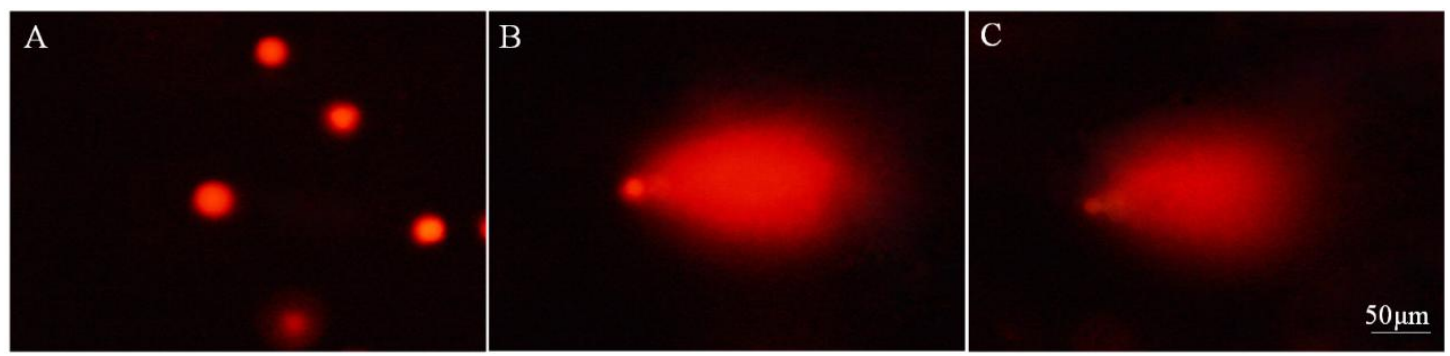

Fig 6. FZD and UVC-induced DNA damage detected by comet assay. A: Control, B: FZD treatment, C: UVC-irradiation.

3.6. GADD45a effect cell proliferation of BRL-3A and FZD/UVC-stimulated cell growth suppression

EdU and MTT were used to test the role of GADD45a on BRL-3A cell proliferation and FZD/UVC -stimulated cell growth suppression. Result of EdU assay showed that GADD45 $\alpha$ overexpression inhibited BRL-3A cell proliferation and attenuated the inhibition of FZD/UVC-induced proliferation of BRL-3A cells, whereas downregulation of GADD45 $\alpha$ promotes cell proliferation and enhances the inhibition of FZD/UVC-induced proliferation of 
bioRxiv preprint doi: https://doi.org/10.1101/148759; this version posted June 11,2017 . The copyright holder for this preprint (which was

not certified by peer review) is the author/funder, who has granted bioRxiv a license to display the preprint in perpetuity. It is made available under aCC-BY-NC 4.0 International license.

BRL-3A cells (Fig 7)..

MTT assay result showed that the up-regulation of GADD45 $\alpha$ gene inhibited the cell viability of BRL-3A cells and promoted viability of BRL-3A that treated by FZD/UVC. While down-regulation of this gene increased the cell viability of BRL-3A cells and reduced the viability of BRL-3A cells treated by FZD and UVC (Fig 8).
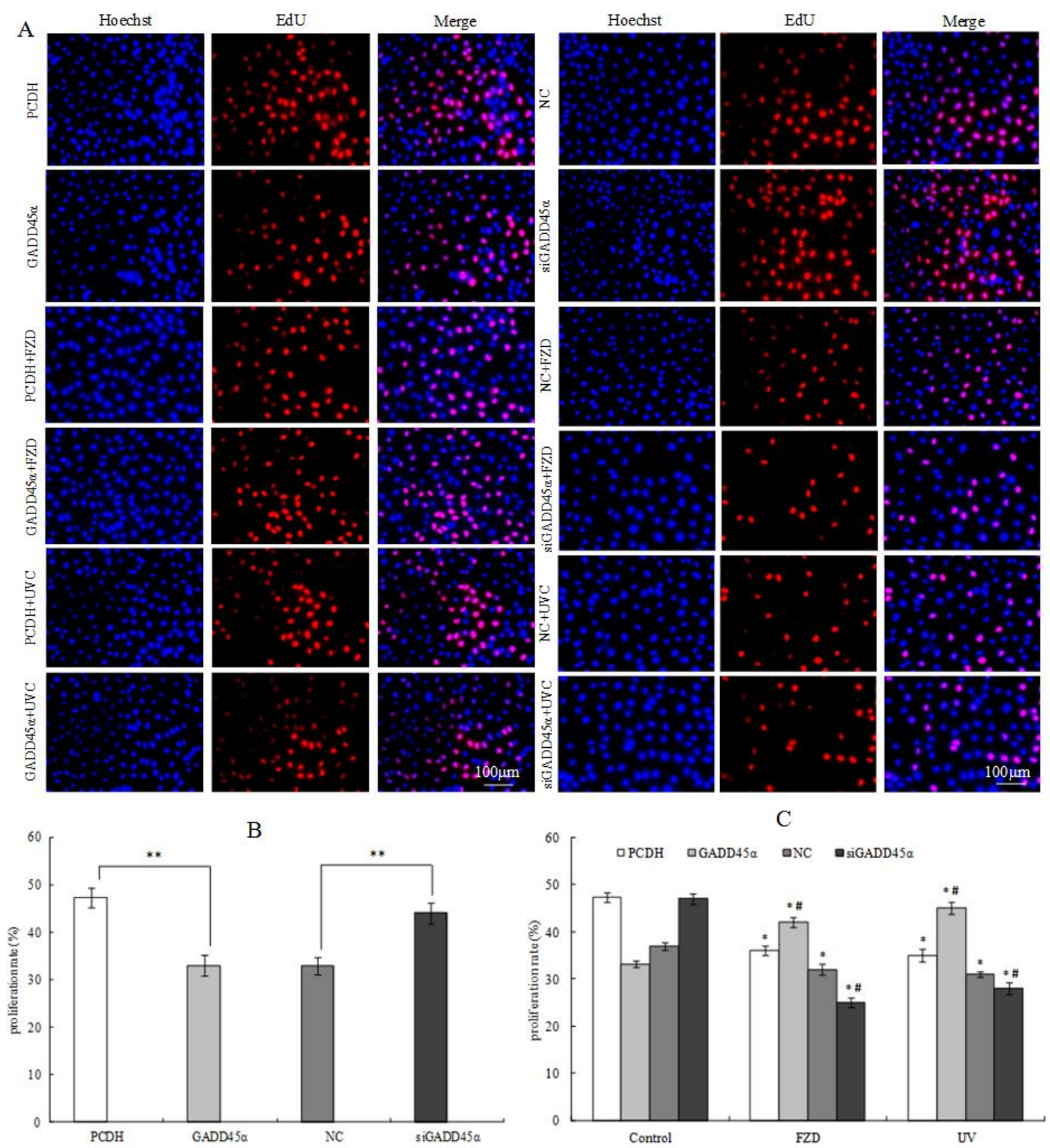

Fig 7. Effects of GADD45 $\alpha$ expression changes on cell proliferation of BRL-3A cells and cells treated by FZD/UVC A: Effects of GADD45 $\alpha$ expression changes on cell proliferation of BRL-3A cells and cells treated by FZD/UVC; B: Effects of GADD45 $\alpha$ expression changes on cell proliferation of BRL-3A cells; C: Effect of GADD45 $\alpha$ expression changes on cell viability of FZD and UVC-treated cells. * $p<0.05, * * p<0.01$ compared with control; \# $p<0.05$ compared with 
control + FZD / UVC
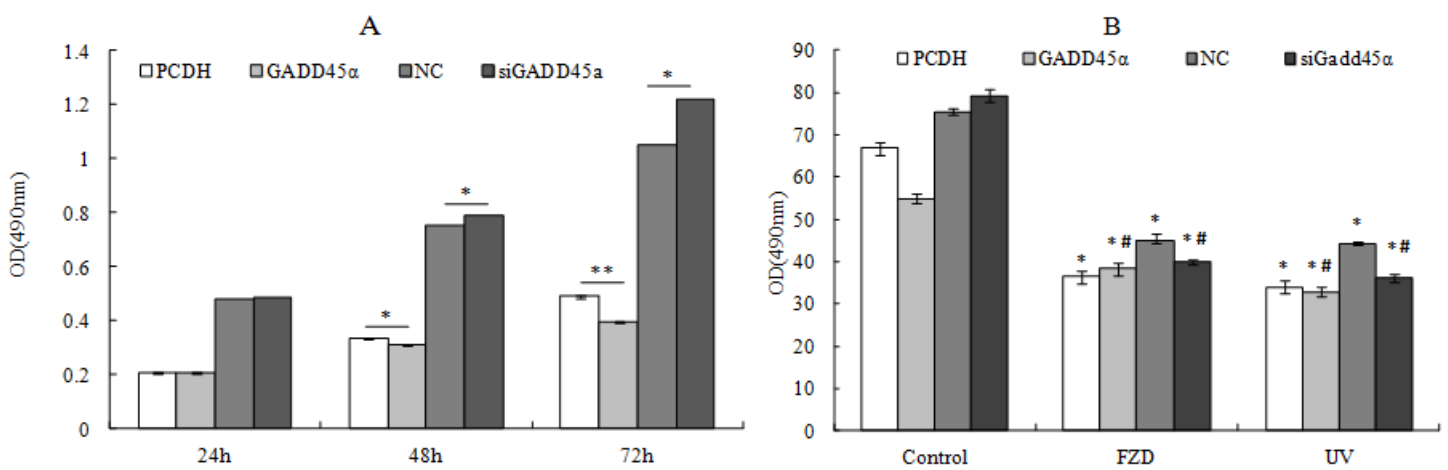

Fig 8. Effects of GADD45 $\alpha$ expression changes on cell viability of BRL-3A cells and BRL-3A cells treated by FZD and UVC A: Effects of GADD45a expression changes on cell viability of BRL-3A cells B: Effect of GADD45 $\alpha$ expression changes on cell viability of FZD and UVC-treated cells $* p<0.05 ; * * p<0.01$ compared with control; \# $p<0.05$ compared with control + FZD/UVC

\subsection{The effect of GADD45 $\alpha$ on cell cycle distribution}

GADD45 $\alpha$ may affect FZD-stimulated S phase cell cycle arrest through a signal transduction network. To test the role of GADD45 $\alpha$ in BRL-3A cells cell cycle and FZD or UVC-stimulated S phase cell cycle arrest, BRL-3A cells were exposed to $50 \mathrm{~g} / \mathrm{mL}$ FZD for $24 \mathrm{~h}$ and UVC for 30s, cell cycle were monitored by flow cytometry. As shown in Fig. 9 FZD and UVC could obviously arouse S-phase cell cycle arrest in BRL-3A cells. When GADD45a low-expressing BRL-3A cells were exposed to FZD for $24 \mathrm{~h}$ and UVC for 30s, proportion of cells in S phase decreased from $43.7 \pm 0.70 \%$ and $37 \pm 0.38 \%$ to $31.5 \pm 0.50 \%$ and $27.5 \pm 0.42 \%$ respectively $(p<0.05$ ), and G2/M phase increased from $5.96 \pm 0.45 \%$ and $11 \pm 0.53 \%$ to $11.2 \pm 0.45 \%$ and $18.3 \pm 0.38 \%$ (P < 0.05 ), whereas G1 phase increased from $50.3 \pm 0.60 \%$ and $52 \pm 0.30 \%$ to $57.4 \pm 0.51 \%$ and $54.2 \pm$ 0.40\%, compared to that of control cells induced by FZD and UVC (Fig. 9, 10). These results indicated that GADD45 $\alpha$ could modulate FZD/UVC-induced S-phase cell cycle arrest.

The results showed that overexpression of GADD45 $\alpha$ significantly inhibited the number of cells in G1 and S phases, while increased the number of cells in G2/M phase of BRL-3A cells and FZD/UVC induced S phase arrest. Downregulated GADD45 $\alpha$ induced the number of cells in S and G2/M phases, while decreased the number of cells in G1 phases of BRL-3A cells and FZD/UVC induced $\mathrm{S}$ phase arrest. 

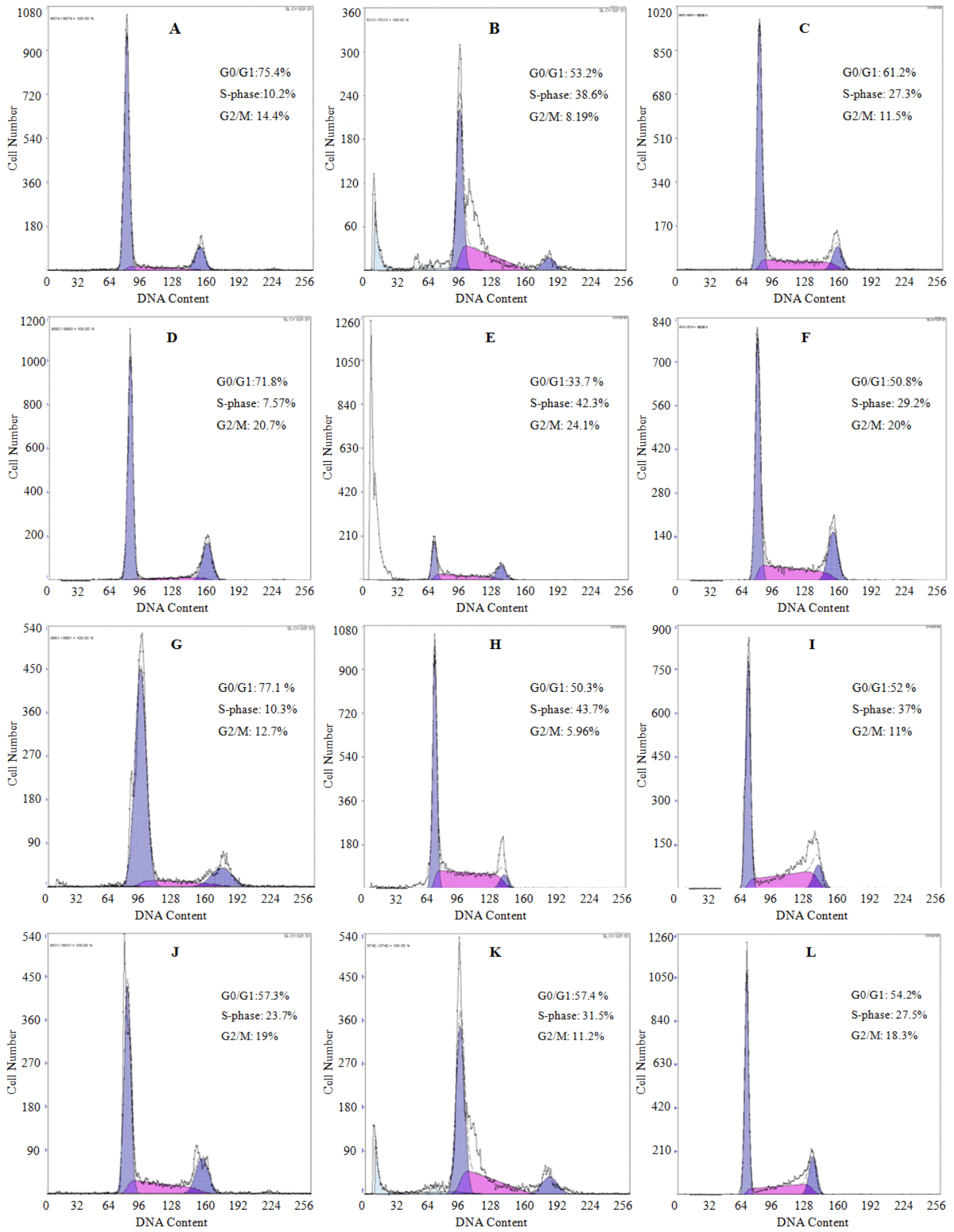

Fig 9. Effects of GADD45 $\alpha$ expression changes on cell cycle of BRL-3A cells and BRL-3A cells treated by FZD /UVC. A: PCDH, B: PCDH+FZD, C: PCDH+UVC, D: GADD45a, E: GADD45 $\alpha+F Z D, F:$ GADD45 $\alpha+U V C$, G: NC, H: NC+FZD, I: NC+UVC, J: siGADD45 $\alpha$, K: siGADD45 $\alpha+F Z D, \quad$ L: siGADD45 $\alpha+$ UVC. 

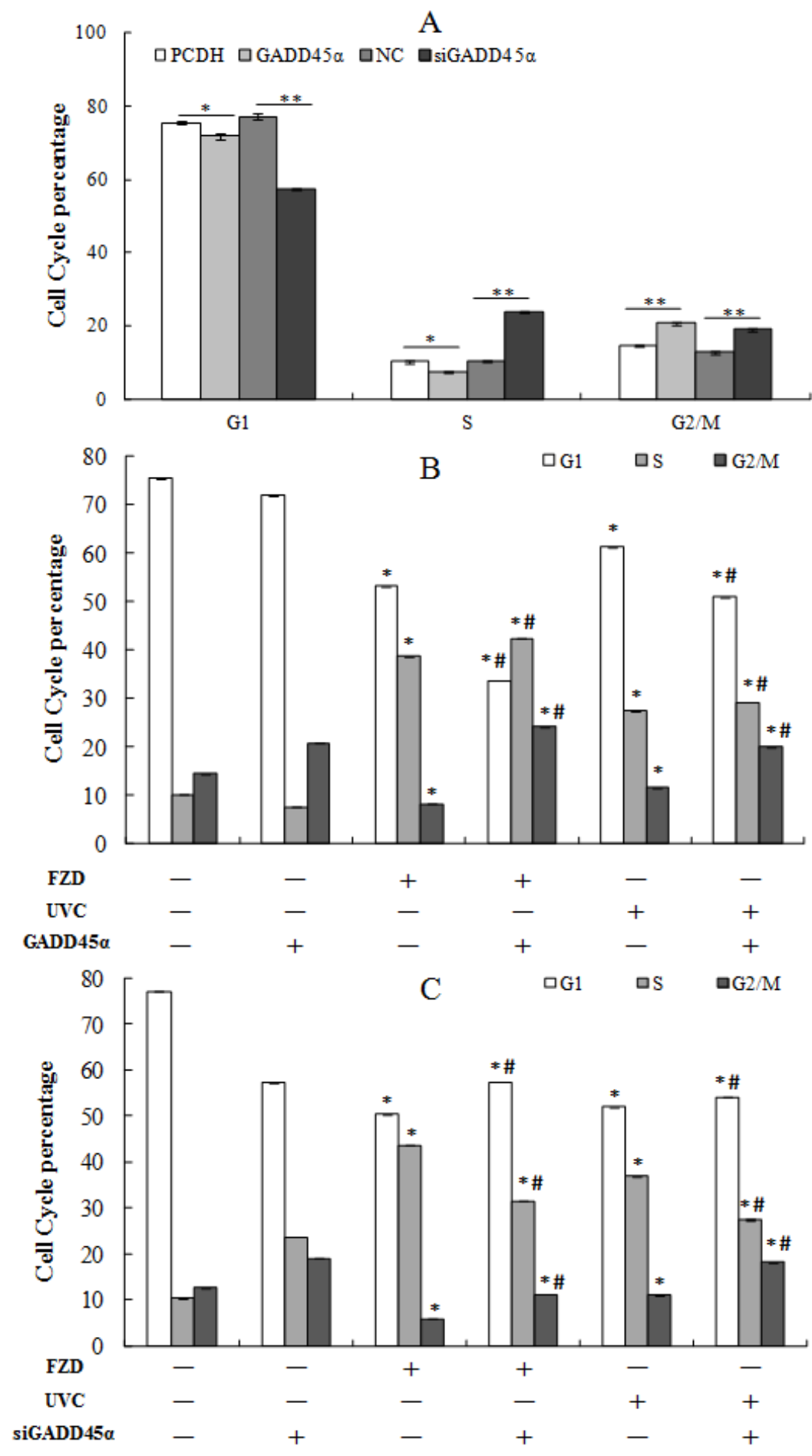

Fig 10. Analysis of the effect of GADD45 $\alpha$ expression on cell cycle of BRL-3A cells and BRL-3A cells treated by FZD/UVC. A: Effect of GADD45 $\alpha$ expression change on cell cycle; B: Effect of GADD45 $\alpha$ expression up-regulation on cell cycle arrest induced by FZD and UVC; C: Effect of GADD45 $\alpha$ down-regulation on FZD and UVC-induced cell cycle arrest. * $p<0.05$ compared with control; \# $p<0.05$ compared with control + FZD/UVC.

\subsection{Effect of GADD45a expression change on cell apoptosis}


The results showed that overexpression of GADD45 $\alpha$ have no effect on the apoptosis of BRL-3A cells, while significantly inhibited the cell apoptosis that induced by FZD/UVC. Downexpression of GADD45 $\alpha$ significantly inhibited the apoptosis of BRL-3A cells, while significantly promoted the cell apoptosis that induced by FZD/UVC (Fig. 11, 12).
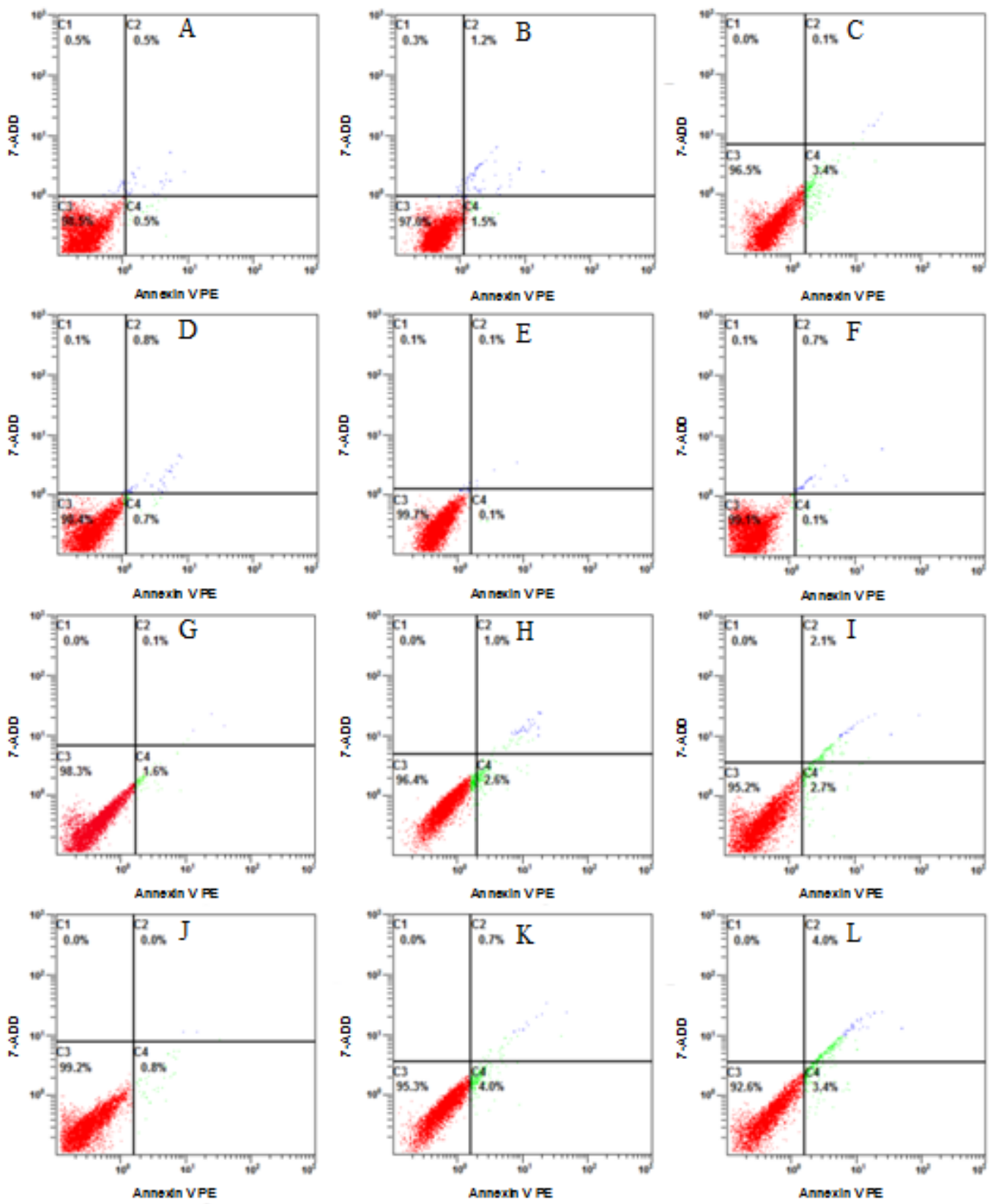

Fig 11. Effects of GADD45 $\alpha$ expression change on the apoptosis of BRL-3A cell and FZD/UVinduced apoptosis

A: PCDH, B: PCDH+FZD, C: PCDH+UVC, D: GADD45 $\alpha$, E: GADD45 $\alpha+F Z D, F:$ GADD45 $\alpha+$ UVC, G: NC, H: NC+FZD, I: NC+UVC, J: siGADD45 $\alpha, \mathrm{K}:$ siGADD45 $\alpha+F Z D$, L: siGADD45 $\alpha+\mathrm{UVC}$. 

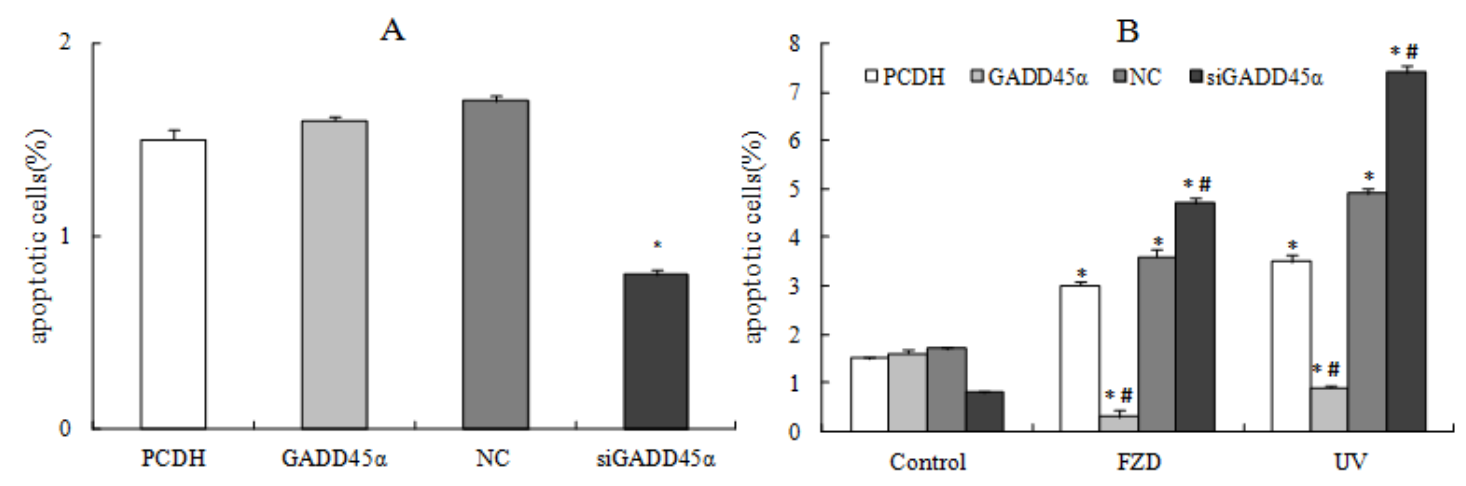

Fig 12. Apoptosis percentage of treated cells. A: Effect of GADD45 $\alpha$ expression change on BRL-3A cells, B: Effect of GADD45 $\alpha$ expression change on apoptosis of BRL-3A cell that treated by FZD/UVC. * $p<0.05$ compared with control; \# $p<0.05$ compared with control + FZD/UVC

\subsection{GADD45a signaling pathway}

GADD45 $\alpha$ signaling pathway was built by the IPA software, and the results showed that GADD45 $\alpha$ could regulate proliferation of cells, DNA repair, G2/M phase, and apoptosis response through P38MAPK, JNK, CDC2/CCNB1, AKT and MTOR signaling pathways (Fig 13).

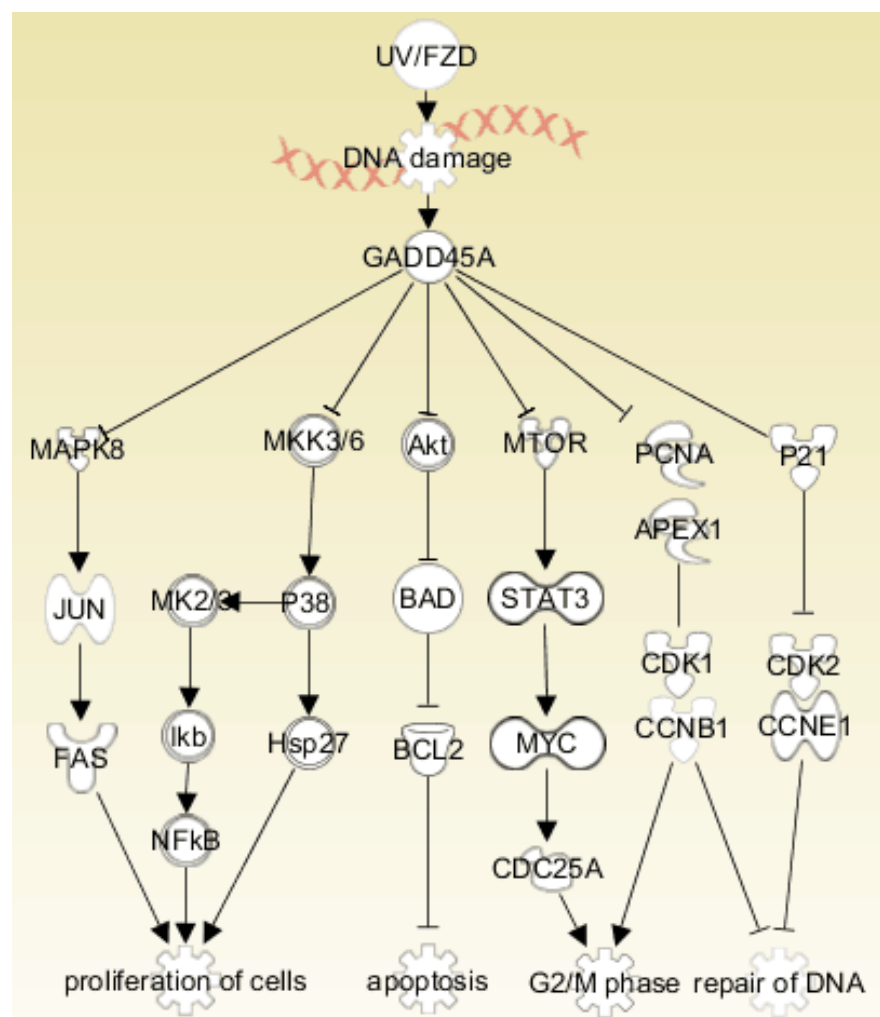

Fig 13. GADD $45 \alpha$ signaling pathway.

3.10. GADD45a expression changes affected the expression of genes/proteins related to

\section{GADD45 $\alpha$ signaling pathway}

To further discover the underlying mechanism of GADD45 $\alpha$ in normal BRL-3A cells and 
FZD/UVC-induced BRL-3A cells on cell cycle and apoptosis, the expression changes of genes-associated with GADD45 $\alpha$ pathway were detected. The results indicated that overexpression of GADD45 $\alpha$ in BRL-3A cells increased the expression of Mapk8, Mapk10, Mapk14, Hsp27, Akt1/3, Myc, Bcl2, NF-kB1, Ccna2 and Ccnd1 were down-regulated at mRNA and protein, while the expression of apoptosis gene-related gene Caspase8 was up-regulated. When down-regulated the expression of GADD45 $\alpha$, the expression of Mapk8/10/14, Hsp27, Akt1/3, Myc, Bcl-2, NF-kB1, Ccnd1 and Ccna2 were up-regulated at mRNA and protein, while the expression of Caspase8 was down-regulated (Fig 14).

The expression changes of genes-associated GADD45 $\alpha$ signaling pathway were detected after treatment with $50 \mu \mathrm{g} / \mathrm{mL}$ FZD or UVC for $30 \mathrm{~s}$ for $24 \mathrm{~h}$. The results showed that overexpression of GADD45 $\alpha$ could decreased the expression of Caspase3, Caspase8, Caspase9 and Bax at mRNA and protein in FZD and UVC-induced BRL-3A cells, and increased the expression of Myc, Bcl-2, Ccnd1, Ccnb1, PCNA and P21. While interfere with GADD45 $\alpha$ expression increased the expression of Caspase8, Caspase9, Bax, Myc and Bcl-2 in FZD and UVC-induced BRL-3A cells, and decreased the expression of Ccnd1, Ccnb1, PCNA and P21 at mRNA and protein (Fig 15).

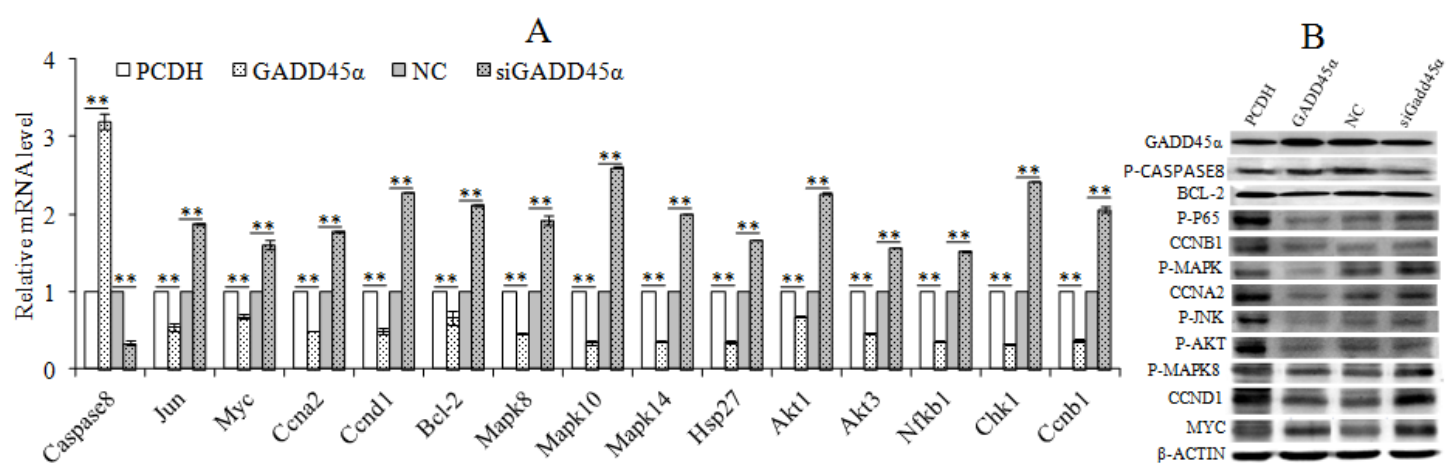

Fig 14. Expression changes of genes/proteins of GADD45 $\alpha$ signaling pathway. A: genes expression level, B: proteins expression level $* * p<0.01$ 

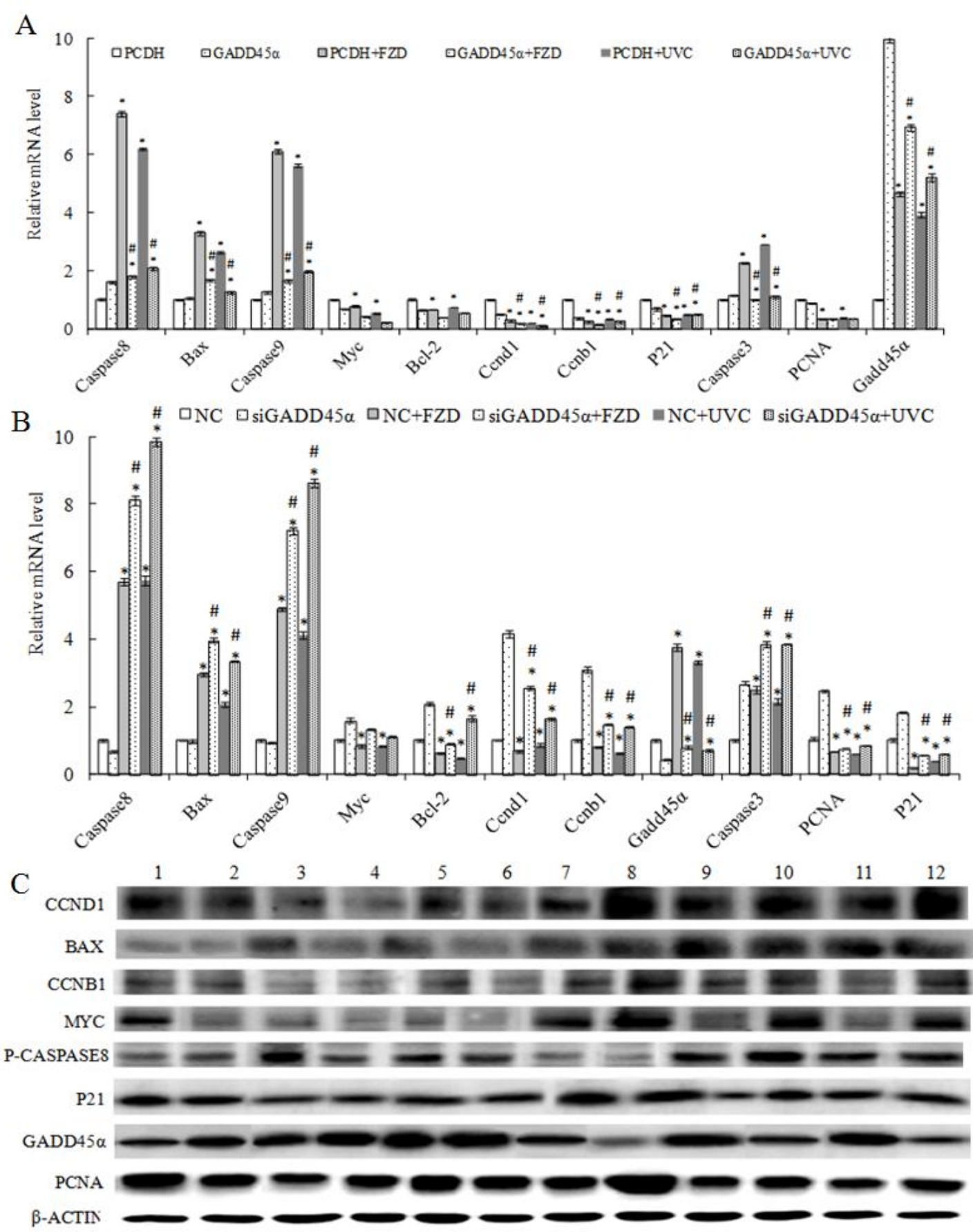

Fig 15. Expression changes of genes/proteins of GADD45 $\alpha$ signaling pathway of BRL-3A cells that treated by FZD/UVC. A: Effect of up-regulated GADD45 $\alpha$ expression on genes expression level; C: Effect of down-regulated GADD45a expression on genes expression level; C: proteins expression level. (* $p<0.05$ compared with control; \# $p<0.05$ compared with control + FZD/UVC).

\section{Discussion}

Studies have shown that GADD45 $\alpha$ was involved in cell cycle, apoptosis, genomic stability, DNA repair, immune response, and the occurrence of cancer. To understand the mechanism of 
GADD45 $\alpha$ in liver regeneration, GADD45 $\alpha$ signal pathway was constructed by several databases such as IPA, KEGG, QIAGEN and the related literature, gene addition and gene interference were used to investigate the effect of GADD45 $\alpha$ on the cell viability, proliferation, apoptosis, cell cycle of BRL-3A and the expression of cell proliferation, apoptosis and GADD45 $\alpha$ signal pathway-related genes/proteins.

In this paper, GADD45 $\alpha$ up-regulated and down-regulated BRL-3A cells were obtained by lentivirus packaging and siRNA interference. The effects of GADD45 $\alpha$ expression on the viability, proliferation, cycle and apoptosis of BRL-3A cells were detected by MTT, EdU and flow cytometry. The results showed that the viability, proliferation, that the number of cells in G1 and S phase, and the expression of proliferation-related genes Myc and Bcl2 of BRL-3A cells were decreased after GADD45 $\alpha$ overexpression, while the number of G2/M phase and expression of apoptosisi-related genes Caspase8 were significantly increased. GADD45 $\alpha$ down regulation could lead to the increase of cell viability, proliferation, the number of cells in G2/M and S phase, and Myc, Bcl2 expression, and the decrease of apoptosis rate and caspase8 expression. Our results indicated that GADD45 $\alpha$ affects the activity and cell cycle of BRL-3A cells by proliferation, apoptosis-related genes/proteins, and ultimately regulates its proliferation and apoptosis.

In P38MAPK signaling pathway, GADD45 $\alpha$ could inhibit P38MAPK via MKK3/6 (Yu et al., 2013), and regulated cell proliferation by MK2/3 $\rightarrow \mathrm{I} \kappa b \rightarrow \mathrm{NF \kappa B}$ (Dong et al., 2002; Tsai et al., 2003) or by Hsp27 (Su et al., 2008). Our study discovered that NFkB and Hsp27 were down-regulated at both mRNA and protein levels when overexpressing GADD45 $\alpha$, whereas NFkB and Hsp27 were up-regulated when GADD45 $\alpha$ was interfered. Therefore, we believe that GADD45 $\alpha$ may regulate BRL-3A cell proliferation through the P38MAPK pathway. In JNK pathway, GADD45 $\alpha$ could inhibit JUN by JNK (David et al., 2002; Tront et al., 2006), and then regulate cell proliferation by FAS (Ivanov et al., 2001). The expression of MAPK8, JUN and FAS were down-regulated at mRNA and protein level after GADD45 $\alpha$ up-regulated, and the expression of MAPK8, JUN and FAS were up-regulated at the mRNA level and protein level after GADD45 $\alpha$ down-regulated, which indicated that GADD45 $\alpha$ may regulate the proliferation of BRL-3A cells through JNK pathway. Studies have shown that in CDC2/CCNB1 pathway, GADD45 $\alpha$ inhibited the kinase activity of the cdc2/cyclin B1 complex by interacting with cdc2 (Cdk1), which regulates the G2-M phase transition of the cell cycle (Liebermann and Hoffman, 2007). In this 
study, it was found that the expression of ccnb1 was down-regulated at both mRNA and protein levels when GADD45 $\alpha$ was overexpressed, while interfered with the GADD45 $\alpha$ expression, the expression of ccnb1 was upregulated, it was suggested that GADD45 $\alpha$ may also regulate the cycle of BRL-3A cells through CDC2/CCNB1 pathway. Studies have shown that knockout of the GADD45 $\alpha$ gene can reduce the expression of Akt protein in the lungs of mice (Meyer et al., 2009). The activated Akt could inhibit the activation of Bad and regulate apoptosis by Bcl-2 (Guo et al., 2011). GADD45 $\alpha$ could inhibit the phosphorylation of STAT3 by interacting with mTOR, and inhibit tumor angiogenesis by blocking the mTOR/STAT3 pathway (Yang et al., 2013). The activation of STAT3 can induce the expression of the target gene c-myc, thereby promoting the expression of Cdc25a and promoting the process of cell cycle (Wang et al., 2011). In AKT and MTOR pathways, Akt, Bcl2 and Myc were down-regulated at mRNA level and protein level when GADD45 $\alpha$ was overexpression. While GADD45 $\alpha$ was down-regulated, the expression of Akt, Bcl2 and Myc in GADD45 $\alpha$ expression was up-regulated, thus indicated that GADD45 $\alpha$ may regulate the proliferation, apoptosis and cycle of BRL-3A cells by AKT and MTOR pathways. In order to investigate the mechanism of GADD45 $\alpha$ on the proliferation and apoptosis of BRL-3A cells, the expression of GADD45 $\alpha$ in BRL-3A cells was detected by qRT-PCR and Western Blot. The results showed that GADD45 $\alpha$ regulate proliferation and apoptosis of BRL-3A cells by regulating the expression of Nfkb1, Mapk14, Mapk8, ccnb1, Akt1 and Myc, and by P38MAPK, JNK, CDC2/CCNB1, AKT and MTOR signaling pathways.

MTT, EdU and flow cytometry were used to detect the effect of GADD45 $\alpha$ on cell viability, proliferation, cycle, DNA repair and apoptosis in FZD/UVC-induced BRL-3A cells. And the results indicated that GADD45 $\alpha$ overexpression significantly increased the activity, cell proliferation, cell cycle arrest in S phase, and Myc, Bcl-2, Ccnd1, Ccnb1, PCNA, P21 expression of BRL-3A cells that treated by FZD/UVC, while decreased the apoptosis rate, and the expression of Caspase3, Caspase8, Caspase9 and Bax. In contrast, down-regulation of GADD45 $\alpha$ expression by RNAi could reduce cell viability, cell proliferation, cell cycle arrest in S phase, and Myc, Bcl-2, Ccnd1, Ccnb1, PCNA, P21 expression in BRL-3A cells that treated by FZD/UVC, while increase cell apoptosis and the expression of Caspase3, Caspase8, Caspase9 and Bax.

GADD45 $\alpha$ could regulate the expression of cell cycle regulatory genes (Kearsey et al., 1995), overexpression of GADD45 $\alpha$ could induce cell cycle arrest (Maeda et al., 2002). DNA damage 
could enhance the activation of GADD45 $\alpha$, and induce cell cycle arrest and maintain genomic stability (Hollander et al., 1999). Gupta et al. found that knockout of the GADD45a gene increased the activation of Caspase-3 protein that induced by UVC radiation in mouse bone marrow cell. GADD45 $\alpha$ and GADD45 $\beta$ interaction could promote cell survival by activating GADD45 $\alpha$-p38-NF-kappaB-mediated survival pathway and inhibiting GADD45 $\beta$-mediated MKK4-JNK stress pathway in hematopoietic cells which exposed to UVC radiation (Gupta et al., 2006). FZD can effectively induce S-phase cell cycle arrest and inhibit cell growth, and increase oxidative induced DNA damage through ROS (Jin et al., 2011). These results indicate that GADD45 $\alpha$ may play an important role in the activation of Myc, Bcl-2, Ccnd1, Ccnb1, PCNA and P21 in FZD/UVC-induced cell cycle arrest in BRL-3A cells. Sun et al. have shown that down-regulation of GADD45 $\alpha$ expression in human liver tumor cells could reduce FZD-induced S-phase cell cycle arrest (Sun et al., 2015). Decreased GADD45 expression attenuated the inhibition of Cdc2/cyclinB1 activity in UV-irradiated human cells (Zhan et al., 1999). GADD45a inhibited Cdc2 kinase activity by altering cyclinB1 subcellular localization to induce cell cycle G2/M arrest and growth inhibition (Jin et al., 2002). Adenovirus-mediated expression of GADD45 $\alpha$ is mediated by caspase activation and cell cycle arrest in G2/M phase (Li et al., 2009). Olaquindox treatment could increase the expression level of GADD45 $\alpha$ protein and reactive oxygen species (ROS), and decrease the mitochondrial membrane potential (MMP), then increase the expression of $\mathrm{Bax}$ and decrease the expression of $\mathrm{Bcl}-2$, and lead to the expression of cytochrome $\mathrm{c}(\mathrm{Cyt} \mathrm{c})$. The down-regulation of GADD45a enhanced the production of ROS induced by quinoline indole, and then increases the activity of caspase-9, caspase-3 (Li et al., 2016).

In summary, GADD45 $\alpha$ may regulate the proliferation, apoptosis and cycle of BRL-3A cells through P38MAPK, JNK, CDC2/CCNB1, AKT and MTOR signaling pathways. GADD45 $\alpha$ may be involved in the DNA repair through Myc, Bcl-2, Ccnd1, Ccnb1, PCNA, P21, Caspase3, Caspase8, Caspase9 and Bax, and then regulate liver regeneration. This study is helpful to understand the mechanism of DNA damage repair that GADD45 $\alpha$ regulated in liver regeneration process, thereby contributing to the prevention and treatment of liver disease. Further studies are still needed in vivo to confirm the mechanism of action of GADD45 $\alpha$.

\section{Acknowledgements}


Funding: This work was funded by the National Natural Science Foundation Project of China (grant No. U1404312), the Science and technology project of Henan Province (grant No. 172102310507), the key scientific research project of universities in Henan Province (grant no. 13A180532), the doctoral Scientific Research Start-up Foundation of HNU (grant No. qd13033), and the Youth Science Foundation of HNU (grant no. 2014). I thank Associate Professor X.G. Yang for his suggestions and comments on the present manuscript.

\section{Conflict of interest statement}

The authors declare no conflict of interest

\section{References}

Bulavin, D. V., Kovalsky, O., Hollander, M. C. and Fornace, A. J., Jr. (2003). Loss of oncogenic $\mathrm{H}$-ras-induced cell cycle arrest and p38 mitogen-activated protein kinase activation by disruption of Gadd45a. Mol Cell Biol 23, 3859-71.

Chang, Q., Bhatia, D., Zhang, Y., Meighan, T., Castranova, V., Shi, X. and Chen, F. (2007). Incorporation of an internal ribosome entry site-dependent mechanism in arsenic-induced GADD45 alpha expression. Cancer Res 67, 6146-54.

David, J. P., Sabapathy, K., Hoffmann, O., Idarraga, M. H. and Wagner, E. F. (2002). JNK1 modulates osteoclastogenesis through both c-Jun phosphorylation-dependent and -independent mechanisms. J Cell Sci 115, 4317-25.

Ding, Y., Chang, C., Niu, Z., Dai, K., Geng, X., Li, D., Guo, J. and Xu, C. (2016). Overexpression of transcription factor Foxa2 and Hnf1alpha induced rat bone mesenchymal stem cells into hepatocytes. Cytotechnology 68, 2037-47.

Dong, C., Davis, R. J. and Flavell, R. A. (2002). MAP kinases in the immune response. Annu Rev Immunol 20, 55-72.

Guo, Q., Jin, J., Yuan, J. X., Zeifman, A., Chen, J., Shen, B. and Huang, J. (2011). VEGF, BCl-2 and Bad regulated by angiopoietin-1 in oleic acid induced acute lung injury. Biochem Biophys Res Commun 413, 630-6.

Gupta, M., Gupta, S. K., Hoffman, B. and Liebermann, D. A. (2006). Gadd45a and Gadd45b protect hematopoietic cells from UV-induced apoptosis via distinct signaling pathways, including p38 activation and JNK inhibition. J Biol Chem 281, 17552-8.

Hollander, M. C., Sheikh, M. S., Bulavin, D. V., Lundgren, K., Augeri-Henmueller, L., Shehee, R., Molinaro, T. A., Kim, K. E., Tolosa, E., Ashwell, J. D. et al. (1999). Genomic instability in Gadd45a-deficient mice. Nat Genet 23, 176-84.

Ivanov, V. N., Bhoumik, A., Krasilnikov, M., Raz, R., Owen-Schaub, L. B., Levy, D., Horvath, C. M. and Ronai, Z. (2001). Cooperation between STAT3 and c-jun suppresses Fas transcription. Mol Cell 7, 517-28.

Jin, S., Tong, T., Fan, W., Fan, F., Antinore, M. J., Zhu, X., Mazzacurati, L., Li, X., Petrik, K. L., Rajasekaran, B. et al. (2002). GADD45-induced cell cycle G2-M arrest associates with altered subcellular distribution of cyclin B1 and is independent of p38 kinase activity. Oncogene 21, 8696-704.

Jin, X., Tang, S., Chen, Q., Zou, J., Zhang, T., Liu, F., Zhang, S., Sun, C. and Xiao, X. (2011). Furazolidone induced oxidative DNA damage via up-regulating ROS that caused cell cycle arrest in 
human hepatoma G2 cells. Toxicol Lett 201, 205-12.

Kearsey, J. M., Coates, P. J., Prescott, A. R., Warbrick, E. and Hall, P. A. (1995). Gadd45 is a nuclear cell cycle regulated protein which interacts with p21Cip1. Oncogene 11, 1675-83.

Lapeyre, B., Bourbon, H. and Amalric, F. (1987). Nucleolin, the major nucleolar protein of growing eukaryotic cells: an unusual protein structure revealed by the nucleotide sequence. Proc Natl Acad Sci U S A 84, 1472-6.

Li, D., Dai, C., Zhou, Y., Yang, X., Zhao, K., Xiao, X. and Tang, S. (2016). Effect of GADD45a on olaquindox-induced apoptosis in human hepatoma G2 cells: Involvement of mitochondrial dysfunction. Environ Toxicol Pharmacol 46, 140-6.

Li, Y., Qian, H., Li, X., Wang, H., Yu, J., Liu, Y., Zhang, X., Liang, X., Fu, M., Zhan, Q. et al. (2009). Adenoviral-mediated gene transfer of Gadd45a results in suppression by inducing apoptosis and cell cycle arrest in pancreatic cancer cell. $J$ Gene Med 11, 3-13.

Li, Z., Gu, T. P., Weber, A. R., Shen, J. Z., Li, B. Z., Xie, Z. G., Yin, R., Guo, F., Liu, X., Tang, F. et al. (2015). Gadd45a promotes DNA demethylation through TDG. Nucleic Acids Res 43, 3986-97.

Liebermann, D. A. and Hoffman, B. (2007). Gadd45 in the response of hematopoietic cells to genotoxic stress. Blood Cells Mol Dis 39, 329-35.

Maeda, T., Hanna, A. N., Sim, A. B., Chua, P. P., Chong, M. T. and Tron, V. A. (2002). GADD45 regulates $\mathrm{G} 2 / \mathrm{M}$ arrest, DNA repair, and cell death in keratinocytes following ultraviolet exposure. $J$ Invest Dermatol 119, 22-6.

Meyer, N. J., Huang, Y., Singleton, P. A., Sammani, S., Moitra, J., Evenoski, C. L., Husain, A. N., Mitra, S., Moreno-Vinasco, L., Jacobson, J. R. et al. (2009). GADD45a is a novel candidate gene in inflammatory lung injury via influences on Akt signaling. FASEB J 23, 1325-37.

Michalopoulos, G. K. and DeFrances, M. C. (1997). Liver regeneration. Science 276, 60-6.

Saintigny, Y., Delacote, F., Vares, G., Petitot, F., Lambert, S., Averbeck, D. and Lopez, B. S. (2001). Characterization of homologous recombination induced by replication inhibition in mammalian cells. EMBO J 20, 3861-70.

Su, X., Ao, L., Zou, N., Song, Y., Yang, X., Cai, G. Y., Fullerton, D. A. and Meng, X. (2008). Post-transcriptional regulation of TNF-induced expression of ICAM-1 and IL-8 in human lung microvascular endothelial cells: an obligatory role for the p38 MAPK-MK2 pathway dissociated with HSP27. Biochim Biophys Acta 1783, 1623-31.

Sun, Y., Tang, S. and Xiao, X. (2015). The Effect of GADD45a on Furazolidone-Induced S-Phase Cell-Cycle Arrest in Human Hepatoma G2 Cells. J Biochem Mol Toxicol.

Tront, J. S., Hoffman, B. and Liebermann, D. A. (2006). Gadd45a suppresses Ras-driven mammary tumorigenesis by activation of c-Jun $\mathrm{NH2}$-terminal kinase and p38 stress signaling resulting in apoptosis and senescence. Cancer Res 66, 8448-54.

Tsai, P. W., Shiah, S. G., Lin, M. T., Wu, C. W. and Kuo, M. L. (2003). Up-regulation of vascular endothelial growth factor $C$ in breast cancer cells by heregulin-beta 1 . A critical role of p38/nuclear factor-kappa B signaling pathway. J Biol Chem 278, 5750-9.

Vairapandi, M., Azam, N., Balliet, A. G., Hoffman, B. and Liebermann, D. A. (2000). Characterization of MyD118, Gadd45, and proliferating cell nuclear antigen (PCNA) interacting domains. PCNA impedes MyD118 AND Gadd45-mediated negative growth control. J Biol Chem 275, 16810-9.

Vairapandi, M., Balliet, A. G., Hoffman, B. and Liebermann, D. A. (2002). GADD45b and GADD45g are cdc2/cyclinB1 kinase inhibitors with a role in $\mathrm{S}$ and G2/M cell cycle checkpoints induced 
by genotoxic stress. J Cell Physiol 192, 327-38.

Wang, H., Lafdil, F., Kong, X. and Gao, B. (2011). Signal transducer and activator of transcription 3 in liver diseases: a novel therapeutic target. Int J Biol Sci 7, 536-50.

Wang, X. W., Zhan, Q., Coursen, J. D., Khan, M. A., Kontny, H. U., Yu, L., Hollander, M. C., O'Connor, P. M., Fornace, A. J., Jr. and Harris, C. C. (1999). GADD45 induction of a G2/M cell cycle checkpoint. Proc Natl Acad Sci U S A 96, 3706-11.

Yang, F., Zhang, W., Li, D. and Zhan, Q. (2013). Gadd45a suppresses tumor angiogenesis via inhibition of the mTOR/STAT3 protein pathway. J Biol Chem 288, 6552-60.

Yu, Y., Li, J., Wan, Y., Lu, J., Gao, J. and Huang, C. (2013). GADD45alpha induction by nickel negatively regulates JNKs/p38 activation via promoting PP2Calpha expression. PLoS One 8, e57185.

Zhan, Q., Antinore, M. J., Wang, X. W., Carrier, F., Smith, M. L., Harris, C. C. and Fornace, A. J., Jr. (1999). Association with Cdc2 and inhibition of Cdc2/Cyclin B1 kinase activity by the p53-regulated protein Gadd45. Oncogene 18, 2892-900. 